\title{
FOUR WEEKS EXERCISE IN VARY INTENSITIES REDUCE MORE INGUINAL FAT THAN PERIGONADAL FAT IN MICE
}

\author{
Ahmad Rukhani Lutfi ${ }^{1}$, Paulus Liben ${ }^{2}$, Lilik Herawati ${ }^{1,2}$ \\ ${ }^{1}$ Sports Health Sciences, Faculty of Medicine, Universitas Airlangga, Surabaya, Indonesia \\ ${ }^{2}$ Department of Physiology, Faculty of Medicine, Universitas Airlangga, Surabaya, Indonesia
}

\begin{abstract}
Physical exercise is a non-pharmacological approach in reducing subcutaneous and visceral fat accumulation. Perigonadal fat $(\mathrm{pgF})$ is part of visceral fat, whereas inguinal fat (ing $F)$ is portion of subcutaneous fat. This study was to analyze the effect of variations in training intensity on $\mathrm{pgF}$ and ingF. This study was randomized posttest only control group design. The subject was female adult mice (Mus musculus) Balb/c (15-20 grams). A total of 24 mice were divided into 4 groups, the control (C), mild-(G1), moderate-(G2), and high-(G3) intensity exercise. The treatment was swimming for 4 weeks, $3 x /$ week. The load of G1 group was 3\% of body weight, G2 was 6\%, G3 was 9\%. Data collected were fasting (FBG) and 2 hours post-prandial $(2 \mathrm{hppBG})$ blood glucose, $\mathrm{pg} F$ and ingF weight. The results showed that FBG and $2 \mathrm{hppBG}$ were insignificant difference. The

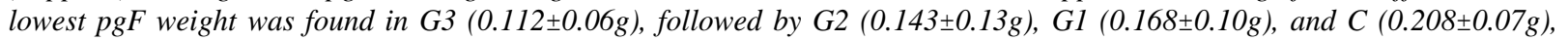
however, there were no significant differences. Meanwhile, the weight of ingF presented significant differences among groups $(p=0.000)$. The lowest weight of ing $F$ was $G 3(0.228 \pm 0.96 g)$, then $G 2(0.298 \pm 0.87 g), G 1(0.329 \pm 0.07 g)$, and the highest was $C$ $(0.552 \pm 0.11 \mathrm{~g})$. The $\mathrm{G1}, \mathrm{G} 2$, and $\mathrm{G3}$ had a significant decrease in ingF weight compared to the control group ( $p<0.05)$, although among G1, G2, and G3 there was insignificant decrease ( $p \geq 0.05$ ). The conclusion indicated that mild, moderate, and high-intensity physical exercise for 4 weeks decrease the weight of inguinal fat and the greatest decrease was through highintensity exercise.
\end{abstract}

Keywords: exercise intensity; glucose; visceral fat; subcutaneous fat; perigonadal fat; inguinal fat

\section{ABSTRAK}

Latihan fisik merupakan pendekatan non-farmakologis untuk mengurangi penumpukan lemak tubuh baik subkutan maupun visceral. Perigonadal fat ( $\mathrm{pgF}$ ) adalah bagian dari lemak visceral dan inguinal fat (ingF) bagian dari lemak subkutan. Tujuan penelitian ini adalah menganalisis pengaruh variasi intensitas latihan terhadap pgF dan ingF. Penelitian ini adalah randomized posttest only control group design. Sampel penelitian adalah mencit betina (Mus musculus) Balb/c dewasa dengan berat badan 15-20 gram. Sebanyak 24 ekor mencit terbagi atas 4 kelompok, yaitu kelompok kontrol (C), latihan intensitas ringan (G1), latihan intensitas sedang (G2), dan latihan intensitas tinggi (G3). Perlakuan berupa renang selama 4 minggu dengan frekuensi 3x/minggu dan pembebanan sesuai kelompok. Kelompok G1 diberikan beban sebesar 3\%, G2 sebesar 6\%, G3 sebesar 9\%. Data berupa glukosa darah puasa (FBG) dan 2 jam post prandial (2hppBG), berat pgF dan ingF. Hasil menunjukkan FBG dan 2 hppBG tidak menunjukkan perbedaan yang bermakna. Berat pgF paling rendah didapatkan pada G3 $(0.112 \pm 0.06 \mathrm{~g})$, disusul G2 $(0.143 \pm 0.13 \mathrm{~g})$, G1 $(0.168 \pm 0.10 \mathrm{~g})$, dan $C(0.208 \pm 0.07 \mathrm{~g})$, namun tidak terdapat perbedaan signifikan. Sedangkan berat ingF menunjukkan perbedaan signifikan antar kelompok $(p=0.000)$. Berat ingF pada G3 paling rendah

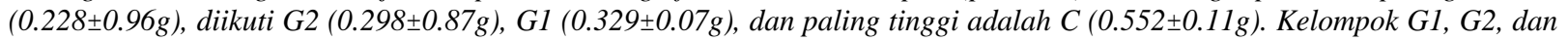
G3 mempunyai penurunan berat ingF bermakna dibanding $C(p<0,05)$, namun antar $G 1$, G2, dan G3 tidak didapatkan penurunan bermakna $(p \geq 0.05)$. Kesimpulan menunjukkan bahwa latihan fisik dengan intensitas ringan, sedang, dan tinggi selama 4 minggu menurunkan berat inguinal fat dan penurunan paling besar adalah latihan dengan intensitas tinggi.

Kata kunci: intensitas Latihan; glukosa; lemak visceral; lemak subkutan; lemak perigonadal; lemak inguinal

Correspondence: Lilik Herawati, Department of Physiology, Faculty of Medicine, Universitas Airlangga/ Sports Health Sciences, Faculty of Medicine, Universitas Airlangga, Surabaya, Indonesia. Email: lilik_heraw@fk.unair.ac.id

pISSN:2355-8393 • eISSN: 2599-056x • doi: 10.20473/fmi.v57i2.18497

- Fol Med Indones. 2021;57:121-128 • Received 04 Apr $2020 \bullet$ Accepted 20 Jul 2020

- Open access under CC-BY-NC-SA license • Available at https://e-journal.unair.ac.id/FMI/ 


\section{INTRODUCTION}

The increasing prevalence of obesity has been very worrying, both in developed and developing countries (Caballero 2007). The prevalence of obesity in women is greater than in men (Chowdhury et al 2018, Weiderpress 2019). In 2016, $13 \%$ of the population or 650 million people aged $>18$ years were obese (World Health Organization 2016). In Indonesia, the prevalence of obesity continues to increase every year. The results of the analysis of Basic Health Research (2018) shows the prevalence of obesity (BMI> 27) of $10.5 \%$ with women is higher around $0.9 \%$ than men in $2007,14.8 \%$ with women is higher around $13.2 \%$ than men in 2013, and in 2018 it is $21.8 \%$.

Obesity is a condition of abnormal or excessive accumulation of body fat that poses a risk to health (World Health Organization 2015) and a factor in the degenerative disease problems (Sudikno et al 2016). Obesity can be a causative factor in increasing the risk of diabetes mellitus (Broskey et al 2018, Wang et al 2015), cardiovascular disease (Koolhaas et al., 2017), various cancers (Chen et al 2012, Ma et al 2013, Marchesini et al 2008, World Cancer Research Fund/ American Institute for Cancer Research 2018, Yang et al 2016), osteoarthritis, and a series of musculoskeletal disorders (Reyes et al 2016). Obesity is often associated with a multifactorial disease due to lifestyle such as unhealthy food or eating habit, and lack of physical activity (Chooi et al 2019). Since the advances and further technology, it leads to lack of physical activity. It is easier for someone to get something without spending a lot of energy. Bad eating habit or unhealthy food and lack of physical activity can bring about the excess energy which will be stored in the form of fat in adipose tissue.

Fat or adipose tissue consists of primary two types namely, white fat tissue and brown fat tissue (Lehnig et al 2018). This study focused on white fat tissue. White fat tissue has functions in energy storage, hormone production, and immune function (Tran \& Kahn 2010). White fat tissue can be categorized into 2 types, namely subcutaneous white fat tissue and visceral white fat tissue.

Subcutaneous white fat tissue can be found mainly around the thighs and buttocks. The excess accumulation of subcutaneous white fat tissue has been linked to insulin sensitivity and type 2 diabetes (Tran \& Kahn 2010). In mice, there are 3 subcutaneous white fat tissue depots including those in inguinal, anterior subcutaneous, and interscapular (Lehnig et al 2019).
Visceral white fat tissue is a fat tissue that surrounds internal organs and excess accumulation of visceral white fat tissue is associated with metabolic disorders. Visceral white fat tissue is part of body fat that is an active hormonal component and has the biochemical character that can influence and trigger pathological processes in the human body (Shuster et al 2012). In mice, there are 6 visceral fat tissue depots found in the perigonadal, mesenteric, perirenal, retroperitoneal, cardiac, and triceps (Lehnig et al 2019), while an increase in visceral fat mass is associated with metabolic dysfunction (Chau et al 2014). The increased abnormally of visceral fat tissue level is known as visceral obesity which can increase the risk of degenerative diseases, it needs preventive and curative efforts. Therefore, the non-pharmacological approach based on physical exercise is an appropriate strategy in increasing fitness and reducing the risk of disease.

Physical exercise has been shown to increase mitochondrial activity in perigonadal fat tissue and inguinal fat tissue (Trevellin et al 2014). Physical exercise can induce secretion of lipolytic hormones which can facilitate greater energy expenditure after exercise and fat oxidation (Irving et al 2008). Physical exercise also has a positive effect on reducing the risk of obesity by lessening body fat stores. During physical exercise, there is a decrease in blood glucose and it stimulates increase hydrolysis of triglycerol to glycerol and free fatty acids as an energy source (Polak et al 2008). The exercise increases growth hormone $(\mathrm{GH})$ (Chaves et al 2013) which has a role in metabolism to stimulate fat to become a dominant source of energy activity than glucose (Karstoft et al 2016) and has more potential in diminishing accumulation of fatty tissue (Wewege et al 2017).

The results of Lehnig et al (2019) showed that running as physical exercise interventions on mice in a running wheel around $7 \mathrm{~km} /$ day or a total distance about $152 \mathrm{~km}$ for 3 weeks, significantly reduced the weight of perigonadal fat depot and inguinal fat in mice. However, the study held by Zhang et al (2017) found that highintensity interval physical exercise and continuous physical exercise in obese women for 12 weeks had no significant effect on body mass, body fat percentage, abdominal fat, and subcutaneous fat. Based on these contradiction, it is important to clarify the effect of variations in exercise especially its intensity on visceral fat and subcutaneous fat. This finding will be important in developing strategies based on physical exercise in obesity prevention to set the adequate exercise intensity.

This study was to determine the effect of physical exercise interventions in various intensity (mild, moderate, and high-intensity) on the weight of 
perigonadal fat $(\mathrm{pgF})$ as part of visceral fat and inguinal fat (ingF) as a one of subcutaneous fat portion in female adult mice to prevent overweight and obesity.

\section{MATERIALS AND METHODS}

This study has received ethical approval from the Health Research Ethics Committee of the Faculty of Medicine, Universitas Airlangga, Surabaya (No.43/EC/KEPK/FKUA/2019). The study was an experimental study with a randomized posttest only control group design. The study was conducted at the Faculty of Veterinary Medicine, Universitas Airlangga, Surabaya.

The subjects of the study were female mice (Mus Musculus) Balb/c, weighing 15-20 grams and 8 weeks of age. The research samples of 24 mice were divided into 4 groups, namely control group (C), mild intensity exercise group (G1), moderate-intensity exercise group (G2), and high-intensity exercise group (G3).

Physical training was swimming by giving loads in the form of a paper clip at the base of the tail tied by a string. The weight of the clip as a load based on bodyweight. The G1 was 3\% of bodyweight, G2 was $6 \%$ of bodyweight, and G3 was $9 \%$ of bodyweight. The acclimatization period before treatment was around 1 week and the duration of the treatmentwas 4 weeks. The frequency was 3 times per week, using the principle of progressive training (gradual improvement) up to 15 minutes. The bodyweight of mice was measured every week to be used as calculation for the loads during swimming training.

The collected data were body weight, fasting blood glucose (FBG) level, 2 hours posy-prandial blood glucose (2hppBG) level, the weight of perigonadal fat tissue (pgF) and inguinal fat (ingF). Before intervention, mice was fasted for 8 hours to perform glucose tolerance test by giving oral gavage of dextrose 20 (D20) solution about $0.1 \mathrm{ml} /$ gram bodyweight to analyze FBG and 2hppBG. Analysis of blood glucose levels was carried out using the Easy Touch GCU portable device. After 4 weeks of treatment, mice were examined again for FBG and 2 hppBG. The next day, the subjects were fasted for 12 hours and anesthetized, and took the pgF and ingF.

\section{RESULTS}

The general characteristics of mice during the study was observed through the changes in bodyweight which showed no significant results $(\mathrm{p}=0.369)$. However, from the average weight, the mild intensity group (G1) had the most increases, while the high-intensity group (G3) had the least weight gain (Figure 1).

Table 1. Average weight before and after intervention in each group

\begin{tabular}{lcc}
\hline Groups & \multicolumn{2}{c}{ Bodyweight } \\
& Pre & Post \\
& mean \pm SD $($ gram $)$ & mean $\pm S D($ gram $)$ \\
\hline C & $17.166 \pm 1.940$ & $22.833 \pm 2.316$ \\
G1 & $17.000 \pm 1.264$ & $23.666 \pm 1.032$ \\
G2 & $17.000 \pm 2.097$ & $22.333 \pm 3.502$ \\
G3 & $17.000 \pm 2.529$ & $22.166 \pm 1.169$ \\
\hline ANOVA p-value & 0.999 & 0.659 \\
\hline
\end{tabular}

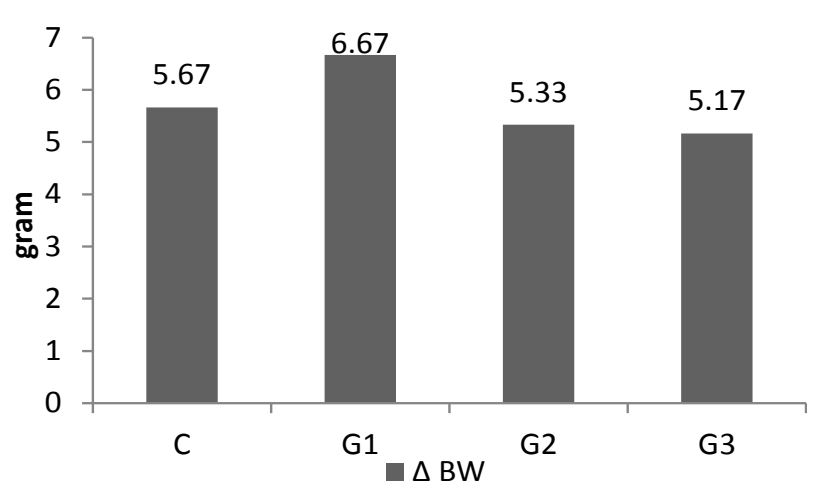

Figure 1. The average bodyweight changing (gram) in each group.

Note: $\mathrm{C}=$ control; $\mathrm{G} 1=$ light intensity exercise; $\mathrm{G} 2=$ moderate intensity exercise; $\mathrm{G} 3=$ high intensity exercise

The levels of FBG and 2hppBG presented insignificant difference ( $p \geq 0.05)$ between groups and the trend of the reducing of blood glucose in each group was also not significant $(\mathrm{p} \geq 0.05)$. 


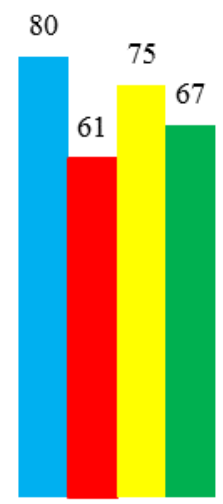

FBG Pre

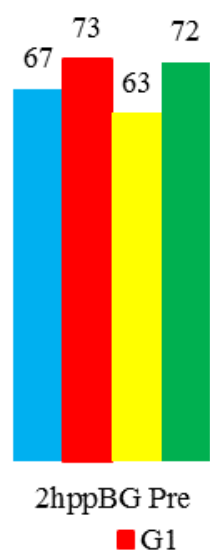

2hppBG Pre

$\mathrm{C}$

G1

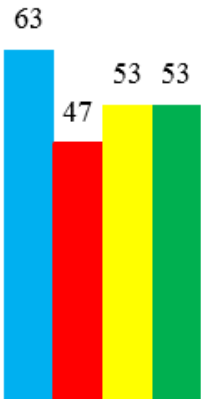

FBG Post

$\mathrm{G} 2$

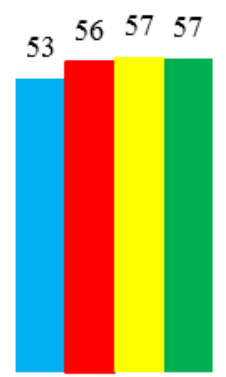

2hppBG Post

Figure 2. The average blood glucose $(\mathrm{mg} / \mathrm{dL})$ in each group
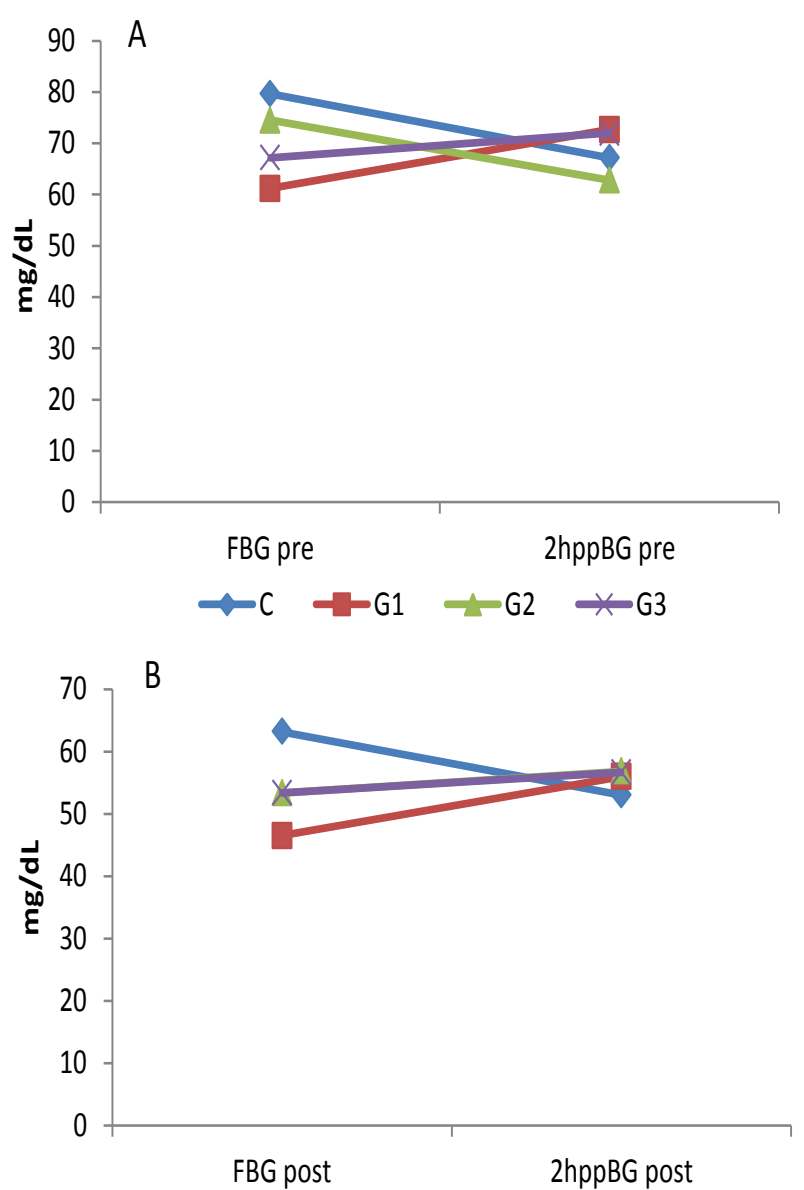

Figure 3. Pattern of blood glucose $(\mathrm{mg} / \mathrm{dL})$ pattern in the timeline.

Note: $\mathrm{C}=$ control; $\mathrm{G} 1=$ light intensity exercise $; \mathrm{G} 2=$ moderate intensity exercise; $\mathrm{G} 3=$ high intensity exercise. $\mathrm{FBG}=$ fasting blood glucose ; $2 \mathrm{hppBG}=2$ hours post prandial blood glucose; Pre $=$ before intervention; Post $=$ after intervention

Based on the perigonadal fat weight $(\mathrm{pgF})$ indicated that the higher the intensity, the lower the weight of $\mathrm{pgF}$
(Figure 4). However, the decrease was not significant among groups $(\mathrm{p}=0.360)$.

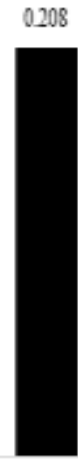

c

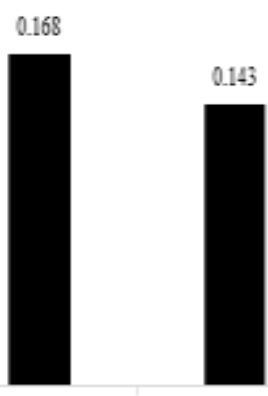

G2

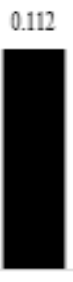

G3
Figure 4. The average weight (gram) of perigonadal fat $(\mathrm{pgF})$ in each group.

Note: $\mathrm{C}=$ control; $\mathrm{G} 1=$ light intensity exercise; $\mathrm{G} 2=$ moderate intensity exercise; G3= high intensity exercise

The decrease in inguinal fat (ingF) was found the same pattern as $\mathrm{pgF}$, but the decrease in ingF was significantly different $(\mathrm{p}=0.000)$ among groups (Figure 5). The ingF decrease in the treatment group (G1, G2, and G3) revealed a significant decrease when compared to the control group (Table 2). Meanwhile, there were no significant differences among the treatment groups $(\mathrm{p} \geq 0.05)$. 


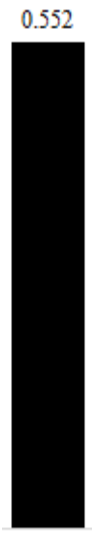

C

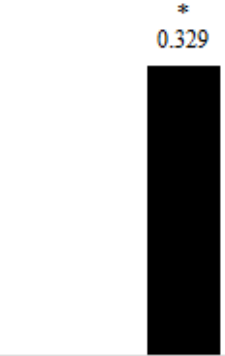

G 1

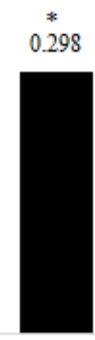

$\mathrm{G} 2$

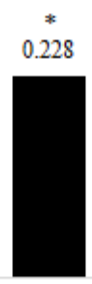

G 3
Figure 5. The average weight (gram) of inguinal fat (ingF) in each group.

Note: $\mathrm{C}=$ control; $\mathrm{G} 1=$ light intensity exercise; $\mathrm{G} 2=$ moderate intensity exercise; G3= high intensity exercise. *sig.diff compared to the control group (analyzed with Anova, posthoc LSD)

Table 2. The results of perigonadal fat $(\mathrm{pgF})$ and inguinal fat (ingF) analysis in each group

\begin{tabular}{ccc}
\hline \multirow{2}{*}{ Groups } & \multicolumn{2}{c}{ Weight } \\
\cline { 2 - 3 } & $\begin{array}{c}\text { pgF mean } \pm \text { SD } \\
(\text { gram })\end{array}$ & $\begin{array}{c}\text { ingF mean } \pm \text { SD } \\
\text { (gram) }\end{array}$ \\
\hline C & $0.208 \pm 0.067$ & $0.552 \pm 0.114^{\mathrm{a}}$ \\
G1 & $0.168 \pm 0.101$ & $0.329 \pm 0.065^{\mathrm{b}}$ \\
G2 & $0.143 \pm 0.128$ & $0.298 \pm 0.872^{\mathrm{b}}$ \\
G3 & $0.112 \pm 0.057$ & $0.228 \pm 0.960^{\mathrm{b}}$ \\
ANOVA $p$-value & 0.360 & 0.000 \\
\hline
\end{tabular}

Note: Different superscripts show that there are significant differences in the post hoc LSD test with $(\mathrm{p}<0.05)$

Table 2 described that the average fat weight of $\mathrm{pgF}$ and ingF in G3 was lower compared to $\mathrm{C}, \mathrm{G} 1$, and $\mathrm{G} 2$. ANOVA test results performed no significant difference in $\mathrm{pgF}$ weight in all groups $(\mathrm{p}>0.05)$, whereas in ingF weight displayed a significant differences among groups $(p<0.05)$. Based on the LSD post hoc test results revealed a significant difference in ingF weight between $\mathrm{C}$ and $\mathrm{G} 1(\mathrm{p}=0,000), \mathrm{C}$ with $\mathrm{G} 2(\mathrm{p}=0,000), \mathrm{C}$ with G3 $(p=0,000)$, while between treatment groups were not significant (G1 and G3, p=0.072; G1 and G2, p=0.563; and $\mathrm{G} 2$ and $\mathrm{G} 3, \mathrm{p}=0.206$ ).

\section{DISCUSSION}

This research study related with variations in the intensity of exercise for 4 weeks on bodyweight, blood glucose, and body fat accumulation. This study used the female adult mice (Mus musculus) Balb/c with a bodyweight of 15-20 grams. Each group had an similar initial average of bodyweight. The average weight of control group was 17.166 grams, the light intensity exercise was 17 grams, the moderate-intensity exercise group was 17 grams, and the high -intensity exercise group was 17 grams. The average final bodyweight in the control group was 22.833 grams, the light intensity exercise group was 23.666 grams, the moderateintensity exercise group was 22.333 grams, and the high-intensity exercise group was 22.166 grams, while the average increase every week in the control group was 5.666 grams, the light intensity exercise group was 6.666 grams, the moderate-intensity exercise group was 5.333 grams, and the high-intensity exercise group was 5.166 grams.

However, after intervening for 4 weeks with varying intensity, the results of this study showed that there were no significant differences in bodyweight between before and after the intergroup interventions $(p<0.05)$. These results are supported by previous studies conducted by Frinchi et al (2013) that with low-intensity aerobic exercise for 4 weeks there was no significant difference in bodyweight. Micallef's study (2015) also found similar outcomes that high-intensity 'Zumba' physical exercise, twice a week for 8 weeks had no significant difference in changing of bodyweight and BMI. The altering weight was insignificant can be due to inadequate training dose to maximize the use of energy reserves used as an energy source during exercise.

Physical exercise can reduce blood glucose levels because of the contracting muscles can optimize the glucose uptake through an increase glucose transporter (Schweitzer et al 2011). Muscle contractions lead to an increase ratio of AMP/ATP and creatinine/phosfocreatinine by activating Adenosine Monophosphate Protein Kinase (AMPK) which act as a mediator of fatty acid oxidation and glucose transport in cells. However, in this study blood glucose levels, both FBG and 2 hppBG, showed insignificant results. A study by Aggarwala et al (2016) also showed insignificant finding, blood glucose before and after aerobic exercise intervention four times a week with 30 minutes in each session for 4 weeks. It might because four weeks physical exercise with intensity variations for 15 minutes in each session can still be tolerated and it can adapt to the load of intervention in the normal subjects.

The pgF weight was insignificant results among groups. The research conducted by Zhang et al (2017) stated similar effect. It was about a high-intensity interval training and moderate-intensity continuous training for 12 weeks which presented no significant difference in body mass, body fat percentage, abdominal fat, and subcutaneous fat in overweight women. Ismail et al 
(2012) also discovered identical output. The aerobic exercise for 4 weeks showed no significant difference in visceral fat weight in overweight person. However, based on this study, the average value of visceral fat weight in the high-intensity exercise group had a tendency to be lower weight compared to the moderateintensity exercise group, control group, and mild intensity exercise group.

The finding corroborates the results of previous research on the fat loss caused by physical exercise (Donnelly et al 2009). The other prior study by Coker et al (2009) indicated that physical exercise for 12 weeks which designed to calories burning about $1000 \mathrm{kcal} /$ week with moderate-intensity and high-intensity also revealed an insignificant reduction in visceral fat, but the highintensity exercise group had reduce visceral fat greater than others without altering level of the adiponectin.

Physical exercise has a positive effect on reducing the risk of obesity by reducing body fat stores. During physical exercise, insulin decrease and glucose uptake which trigger by muscle contradiction can lead to decrease blood glucose level. Physical exercise also stimulates increase hydrolysis of triglycerol to glycerol and free fatty acids as an energy source (Polak et al 2008). The different variations in the intensity of physical exercise affect the fat catabolism, especially visceral fat, as a source of energy during exercise. Physical exercise induces secretion of lipolytic hormones which can facilitate greater energy expenditure after exercise and fat oxidation (Irving et al 2008). Lipolytic hormones such as catecholamines and growth hormone $(\mathrm{GH})$ increase depending on the intensity of the exercise. High-intensity exercise induces an increase in catecholamine production to increase lipolytic body fat stores as a source of energy during exercise.

Furthermore, increased fat loss during recovery from high-intensity is associated with growth hormone release (Zhang et al 2017). Lipolytic action induced by high-intensity exercise is greater in visceral fat than subcutaneous fat (Trapp et al 2007). Lipolytic action which is induced by exercise intensity is also influenced by several factors including gender and body composition (Kuk \& Lee 2019). In women, the energy source during and after exercise is more focused on fat metabolism than men who are more dominant on carbohydrate metabolism (Henderson 2014, Tarnopolsky et al 2007).

Variations in exercise intensity have a significant effect on ingF weight loss. A reduce weight of ingF was significant difference between control and mild intensity exercise, control and moderate intensity exercise, and control and high intensity exercise, while mild and high intensity exercise, mild and moderate intensity exercise, and mild and high intensity exercise did not show a significant difference. These results were linier with the research conducted by Pistor et al (2014) which disclosed that high-intensity exercise for 6 weeks gave a significant effect on decreasing ingF.

The decrease in ingF in physical exercise group is due to the the body increases energy expenditure and increases the lipolytic action on fat depots as an energy source during exercise by activating the oxidation of fatty acids. Higher levels of fatty acid oxidation will help to maintain intracellular energy levels, nevertheless it is still less fatty acids available for re-esterification in cells. Re-esterification in subcutaneous fat tissue especially inguinal fat has been reported having positive linier correlation with the level of lipolysis (Pistor et al 2014). Exercise can also reduce ingF accumulation by increasing the change in ingF to brown fat. During highintensity exercise ingF is induced by myokine released during exercise (irisin) derived from cleavage of protein 5 containing fibronectin domain (FNDC5) which promotes browning (Micelle et al 2014).

\section{CONCLUSION}

The mild, moderate, and high intensity of physical exercise for 4 weeks could decrease weight of inguinal fat (part of subcutaneous fat) more than perigonadal fat (one of visceral fat). The largest reducing was high intensity exercise. However, further research needed to be conducted to uncover the mechanism that is responsible for the reducing of fat store, such as hormones or enzymes.

\section{ACKNOWLEDGMENT}

The authors thank Study Program of Sports Health Science and Department of Physiology, Faculty of Medicine, Universitas Airlangga for their facilitation on this work. Besides, the authors express gratitude to all team members at the embryology laboratory, Faculty of Veterinary Medicine, Universitas Airlangga, for the technical assistance during the research.

\section{REFERENCES}

Aggarwala J, Sharma S, Saroochi, et al (2016). Effects of aerobic exercise on blood glucose levels and lipid profile in diabetes mellitus type 2 subjects. Al Ameen Journal Medicine Science 9, 65-69. 
Basic Health Research (2018). Hasil utama riset kesehatan dasar. Jakarta, Ministry of Health of the Republic of Indonesia.

Broskey NT, Obanda DN, Burton JH, et al (2017). Skeletal muscle ceramides and daily fat oxidation in obesity and diabetes. Metabolism 82, 118-123.

Caballero B (2007). The global epidemic of obesity: An overview. Epidemiol Rev 29, 1-5.

Chau YY, Bandiera R, Serrels A, et al (2014). Visceral and subcutaneous fat have different origins and evidence supports a mesothelial source. Nat Cell Biol $16,367-375$.

Chaves VE, Junior FM, Bertolini GL (2013). The metabolic effects of growth hormone in adipose tissue. Endocrine 44, 293-302.

Chen Y, Wang X, Wang J, et al (2012). Excess body weight and the risk of primary liver cancer: An updated meta-analysis of prospective studies. Eur $\mathbf{J}$ Cancer 48, 2137-45.

Chooi YC, Ding C, Magkos F (2019). The epidemiology of obesity. Metabolism 92, 6-10.

Chowdhury MAB, Adnan M, Hassan Z (2018). Trends, prevalence and risk factors of overweight and obesity among women of reproductive age in Bangladesh: a pooled analysis of five national cross-sectional surveys. BMJ Open 8, 1-12.

Coker RH, Williams RH, Kortebein PM, et al (2009). Influence of exercise intensity on abdominal fat and adiponectin in elderly adults. Metab Syndr and Relat Disord 7, 363-8.

Donnelly JE, Blair SN, Jakicic JM, et al (2009). Appropriate physical activity intervention strategies for weight loss and prevention of weight regain for adults. Med Sci Sports Exerc 41, 459-71.

Frinchi M, Malacuso F, Licciardi A, et al (2013). Recovery of damaged skeletal muscle in mdx mice through low-intensity endurance exercise. Int J Sport. Med 35, 19-27.

Henderson GC (2014). Sexual dimorphism in the effects of exercise on metabolism of lipids to support resting metabolism. Frontiers in Endocrinology 5, 1-8.

Irving BA, Davis CK, Brock DW, et al (2008). Effect of exercise training intensity on abdominal visceral fat and body composition. Med Sci Sports Exerc 40, 1863-72.

Ismail ISE, Keating MK, Baker, et al (2012). A systematic review and meta-analysis of the effect of aerobic vs. resistance exercise training on visceral fat. Obes. Rev 13, 68-91.

Karstoft K, Gareth A, Wallis BK, et al (2016). The effects of interval- vs. continuous exercise on excess post-exercise oxygen consumption and substrate oxidation rates in subjects with type 2 diabetes. Metabolism: Clinical and Experimental 65, 1316-25.

Koolhaas CM, Dhana K, Schoufour JD, et al (2017). Impact of physical activity on the association of overweight and obesity with cardiovascular disease: The Rotterdam study. European Journal of Preventive Cardiology 24, 934-941.

Kuk JL, Lee SJ (2019). Sex and ethnic differences in the relationship between changes in anthropometric measurements and visceral fat in adolescents with obesity. J Pediatr 213, 121-127.

Lehnig AC, Dewal RS, Baer LA, et al (2019). Exercise training induces depot-specific adaptations to white and brown adipose tissue. iScience 11, 425-439.

Lehnig AC, Stanford KI (2018). Exercise induced adaptations to white and brown adipose tissue. J Exp Biol 221, 1-8.

Ma Y, Yang Y, Wang F, et al (2013). Obesity and risk of colorectal cancer: A systematic review of prospective studies. PLoS ONE 8, 1-16.

Marchesini G, Moscatiello S, Domizio SD, et al (2008). Obesity-associated liver disease. Journal of Clinical Endocrinology and Metabolism 93, S74-80.

Micallef C (2014). Associations of weight loss in relation to age and body mass index in a group of Maltese overweight and obese women during an 8week Zumba programme. Sport Sci Health 11, 97102.

Pistor KE, Sepa-Kishi DM, Hung S, et al (2015). Lipolysis, lipogenesis, and adiposity are reduced while fatty acid oxidation is increased in visceral and subcutaneous adipocytes of endurance-trained rats. Adiposyte 4, 22-31.

Polak Jan, Bajzova M, Stich V (2008). Effect of exercise on lipolysis in adipose tissue. Future Lipidology 3, 557-572.

Reyes C, Leyland KM, Peat G, et al (2016). Association between overweight and obesity and risk of clinically diagnosed knee, hip, and hand osteoarthritis: A population-based cohort study. Arthritis Rheumatol 68, 1869-75.

Schweitzer GG, Castorena CM, Hamada T, et al (2011). The B2 receptor of bradykinin is not essential for the postexercise increase in glucose uptake by insulinstimulated mouse skeletal muscle. Physiol Res 60, 511-519.

Shuster A, Patlas M, Pinthus JH, et al (2012). The clinical importance of visceral adiposity: A critical review of methods for visceral adipose tissue analysis. Br J Radiol 85, 1-10.

Sudikno, Syarief H, Dwiriani CM, et al (2016). Faktor risiko obesitas sentral pada orang dewasa umur 25-65 tahun di Indonesia: Analisis data riset kesehatan dasar 2013. The Journal of Nutrition and Food Research 38, 111-120.

Tarnopolsky MA, Rennie CD, Robertshaw HA, et al (2007). Influence of endurance exercise training and sex on intramyocellular lipid and mitochondrial ultrastructure, substrate use, and mitochondrial 
enzyme activity. Am J Physiol Regul Integr Comp Physiol 292, R1271-8.

Tran TT, Kahn CR (2010). Transplantation of adipose tissue and stem cells: role in metabolism and disease. Nat Rev Endocrinol 6, 195-213.

Trapp EG, Chisholm DJ, Boutcher SH (2007). Metabolic response of trained and untrained women during high-intensity intermittent cycle exercise. American Journal of Physiology - Regulatory Integrative and Comparative Physiology 293, R23705.

Trevellin E, Scorzeto M, Olivieri M, et al (2014). Exercise training induces mitochondrial biogenesis and glucose uptake in subcutaneous adipose tissue through eNOS-dependent mechanisms. Diabetes 63, 2800-2811.

Wang C, Li J, Xue H, et al (2015). Type 2 diabetes mellitus incidence in Chinese: Contributions of overweight and obesity. Diabetes Res Clin Pract 107, 424-32.

Weiderpass E, Botteri E, Longenecker JC, et al (2019). The prevalence of overweight and obesity in an adult Kuwaiti population in 2014. Front Endocrinol 10, 1-9.
Wewege M, Berg RVD, Ward RE, et al (2017). The effects of high- intensity interval training vs. moderate-intensity continuous training on body composition in overweight and obese adults: A systematic review and meta- analysis. Obes Rev 18, 635-646.

World Cancer Research Fund (2018). Diet, nutrition, physical activity and breast cancer: Continuous update project expert report. America, American Institute for Cancer Research.

World Health Organization (2015). Obesity and overweight. Swiss, World Health Organisation.

World Health Organization (2016). Media centre obesity and overweight. Swiss, World Health Organization.

Yang L, Drake BF, Colditz GA (2016). Obesity and other cancers. Journal of Clinical Oncology 34, 42314237.

Zhang H, Tong TK, Qiu W, et al (2017). Comparable effects of high-intensity interval training and prolonged continuous exercise training on abdominal visceral fat reduction in obese young women. J Diabetes Res 2017, 1-9. 